\title{
Shopping Behavior Among Urban Women
}

\author{
Muhammad Wahyuddin \\ Anton A Setyawan \\ Sidiq Permono Nugroho \\ Faculty of Economic and Business Universitas Muhammadiyah Surakarta \\ Jl. A Yani Tromol Pos 1 Pabelan Kartasura \\ Corresponding Emails: muhammad.wahyuddin@ums.ac.id,anton.setyawan@ums.ac.id
}

Doi:10.5901/mjss.2017.v8n1p306

\section{Abstract}

This research was aimed to analyze the difference of men and women in Surakarta in perceiving the shopping value. The values were classified into the hedonic and utilitarian value. Hedonic value occurs when consumers rely on their emotional, social, and psychological aspect, while utilitarian value is more concerned with the functional aspect in carrying out the activity. Result showed that there was difference perception between men and women as retail consumers. In this study, women tended to have hedonic value as their shopping orientation, while men tended to have utilitarian orientation. It implied that gender was an important aspect in structuring business position and segmentation in retail industry.

Keywords: shopping value, hedonic, utilitarian, gender.

\section{Background}

In modern cities, the existence of department stores involve both positive and negative implications. It has several positive impacts in the realm of economic boost and job creation. However, it also has negative implications since department store stirs consumptive behavior among society (Kelly et al., 2015; Shandilya, 2014). The consumptive behavior is marked by unplanned emotional-oriented purchase (Duarte et al., 2013). Emotional purchase is an outcome of stimulus from service providers which tempts consumers, for example, a consumer goes window shopping to a supermarket and spots discount tags on some particular products which eventually stimulate the consumer to make a purchase even though the product is unplanned and unneeded (Bagdaiyan and Verma, 2015).

Karim et al. (2013) stated that there was a relationship between shopping behavior and gender. Furthermore, since the marketing teams were fully aware of this phenomenon, they considered the gender's propensity to create the shopping stimulus. Karim et al. (2013) found that women consumers tended to buy stuffs mostly by considering the emotional and feeling aspects. Seock and Souls (2008) proposed the same idea that women tended to be more easily contracted by compulsive purchase that made them became more consumptive than men.

This study analyzed the shopping behavior among urban women in a modern city in Indonesia. We used hedonic and utilitarian shopping behavior as the framework in this study (Assael, 1998; Griffin et al, 2000). Assael (1998) defined utilitarian as consumers who decide to purchase a thing mainly to meet their needs regardless the convenience aspect of the shopping area. The hedonic consumers behave differently. They consider the convenience and recreation aspects as the most important aspects in shopping activity. The hedonic consumers are also attached to the emotional aspects in their shopping behavior.

This study also analyzed the differences of shopping behavior between urban men and women in a modern city. This study tested whether women consumers have higher hedonic shopping behavior than men consumers.

\section{A Structural Model of Fashion-Oriented Impulse Shopping Behavior}

Park et al. (2006) explored structural model to test the engagement between behaviors, positive emotions, and hedonic consumption trends of colleges in The United States. This study provided an insight for retailers and researchers to understand the structural relationship between consumers characteristic and user-oriented buying behavior. The research found that user involvement and positive emotion directly affected purchase motivation. Moreover, there was an 
implication that the two models in the study, involvement and positive emotion were important predictors to the purchase motivation. In the structural model, purchase motivation can be predicted from components of attitude (e.g. fashion involvement) and emotional factors (e.g. satisfied, enthusiastic) among young consumers. For this kind of example, user involvement was affected by purchase motivation, which supported the strong relationship between product involvement and tendency to purchase a specific product (Jones et al., 2003; Seo et al., 2001).

Based on hedonic perspective, positive emotions increase purchase motivation, whereas hedonic consumption is not directly related to purchase behavior. These findings suggested that for certain types of consumer, purchase motivation was more aligned with the emotional factors underlying the unplanned clothing purchase (Cha, 2001). Furthermore, these findings supported the hedonic satisfaction or emotional satisfaction through impulse buying (Hausman 2000; Piron, 1991) and showed that hedonic consumption had indirect influence on purchase motivation. Retailers must consider the positive emotion of consumers and their hedonic experiences in the department stores as it can lead to unplanned purchase of fashion products. In addition, retailers need to continuously encourage the impulse of consumers' purchase and positive emotion through store design, product display, packaging design, and sale. Attempts to increase the market share of fashion to shift from one product advantage and the merchandise breadth, depth, and quality added the emphasis in creating joyfulness and something attractive for consumers who were more interested on just a product. Retailers might offer different products or perform pricing strategies or differentiate their stores by establishing a bridge between stores' atmosphere and consumers' emotional condition. Hence, even if the consumers are in negative emotion, their emotions might be increased and eventually they spend more money than what has been planned previously. Customers were expected to feel more comfortable ina place with attractive layout, good cleanliness, colorful and effective sale.

\section{Integrative Framework of Utilitarian Shopping Experience}

Fiore and Kim (2007) made remarks that along with the changes in consumer demand, model for empirical study on shopping experience has also evolved that reflects the nature of integrative (experience and utilitarian) shopping experience. This research was aimed to propose a comprehensive stimulus-organism-response based on shopping experience framework. Fiore and Kim (2007) provided an overview of conceptual framework integrating both hedonic experience related to emotional awareness values and utilitarian experience related to cognition that affects behavior models.

The framework developed by Fiore and Kim (2007) supported researchers in developing empirical study on vague shopping experience and utilitarian approach in the shopping experience. Moreover, the findings in the research would be suitable to investigate the correlation between shopping experiences and other components for example, to explore the influence of pre-existing mood on cognitive aspects to the previous direction and shopping experience. Eventually, the impacts of the variables on the change that influence consumers and the patronage intention to go on the store can be explored. The methodology (observation and verbal data in the actual retails) helped researches to accurately capture the mood, emotion, and cognitive of the environmental cues in the store, as well as to uncover the role of mood and cognitive that shaped values and behaviors.

Babin and Babin (2001) showed that the nature of experience development and utilitarian value resulted from the pre- and post-shopping experience on a product. It indicated the perceived value associated with a product or brand was likely to change during the post-purchase discussion that occurred in the online communities centered on a product category (e.g. bags and shoes) or brand. In the future, researcher can explore the role of perceived value that appears from more complete product experience in related to behavior variables. The shopping experience framework and the shopping advantage can also guide industry in developing successful shopping experience. For instance, emotion that was generated from consciousness and fostered by store display could establish an attachment ona product (Isen et al, 1992; Meloy, 2000; Lee and Sternthal, 1999). The relationship among the involved variables must be considered during the development of retail environment that is designed to reflect the brand in long-termed strategy.

\section{Hedonic Shopping: Consumer's Pleasure and Experience}

Millan and Howard (2007) examined the shopping behavior and motive in shopping centers in Hungary to analyze the level of hedonic shopping value among consumers. Consumers' consumptive habits in Hungary seemed to be a working activity despite the country's retail industry grew rapidly. The segments of the buyers could be identified by using cluster analysis: relaxed utilitarian, strict utilitarian, committed customers, and browsers. In addition, related with the motives, most of the Hungarian consumers made decision on what they wanted to buy before visiting a store, hence, the 
marketing team must focus in providing information about retail deals in advance. However, social interaction and recreational facility to attract the consumers' visit did not work properly in Hungary.

This result of previous study also indicated that the motivation of most of consumers in shopping centers in Hungary was mainly to purchase products rather than to have a sort of experience. Nearly 60 percent of respondents agreed or strongly agreed that they went shopping to see or find specific products or new products as well as tohunt for luxury goods. Meanwhile, they disagreed that they went shopping for experience intention. Similarly, Hungarian consumers were more likely to show a greater value in completing their shopping list in an efficient manner rather than to obtain amusement and emotional value of shopping. The consumers who agreed that utilitarian shopping was more important, was triples higher than those who agreed that hedonic shopping experience was more important.

\section{Gender and Shopping Behavior}

Several studies have shown that shopping behavior is distinguished by a number of demographic factors. The demographic factors include gender, age, marital status, and income (Seock and Souls, 2008; Karim et al., 2013), employment and income (Tai, 2008), and the number of family members (Samuel et al., 1996).

Seock and Souls (2008) analyzed shopping behavior of apparel products among Hispanic and European ethnic in which the findings showed the insignificant fundamental differences between the two ethnics related to shopping behavior on apparel products. However, men and women differ in evaluating the apparel products and shopping orientation (Seock and Souls, 2008). Based on this study, a hypothesis could be composed as follows:

$\mathrm{H}_{1}$ Gender has a contribution on consumers shopping behavior in which men has lower level of desire in shopping than women.

Karim et al. (2013) examined the PSV instruments on retail industry consumers in Malaysia, which implied that there were differences in consumer shopping behavior of retail industry, namely, hedonic and utiliarian orientation. According to the finding of this study, the hedonic shopping orientation had better measurement than the utilitarian shopping orientation, based on gender, age, and marital status. Samuel et al. (1996) carried out a study regarding with shopping orientation of food products in Shanghai that found out men tended to go shopping for functional reasons while women considered emotional and psychological reasons. Based on this study, a hypothesis was composed as follows:

$\mathrm{H}_{2}$ Gender has a contribution on hedonic shopping behavior in which men has lower level of hedonic shopping behavior than women.

Tai (2008) examined the effect of self-worth towards shopping orientation by involvingthe working-class consumers in Shanghai, Taipei, and Hong Kong as the respondents. The result showed that life style and self-actualization provided dominant influence on shopping orientation. The study clarified the insignificant effects of economic motivation and gender on the shopping orientation of retail consumers among urban workers in Shanghai, Taipei, and Hong Kong. Based on this study, a hypothesis was composed as follows:

$\mathrm{H}_{3}$ Gender has a contribution on utilitarian shopping behavior in which men has lower level of utilitarian shopping behavior than women.

\section{Research Methods}

\subsection{Population and Sample}

Population and samples of this study were the consumers of department store in Solo. Solo is a modern city in Indonesia with rapid growth of retail industry. In the condition of unknown population frame, there was no guidance to determine the exact number of samples. In this condition, the basic rule is large sample could give more information (Hair et al. 2010). Sample size in this study was decided based on the analysis tool which was multivariate statistic. Hair et al. (2010) stated the multivariate model with less than 5 variables requires 150 samples. This study involved 200 respondents selected by using purposive sampling method. The respondents were men and women who visited department stores at least once a month.

\subsection{Measurement Scales and Variables}

This Study used the Personal Shopping Value (PSV) research instrument (Griffin et al. 2000) with Likert scale of 1 for strongly disagree to 5 for strongly agree. The variables in this study consisted of constructed shopping values which were measured from the lower-order construction: hedonic and utilitarian value. 
Utilitarian shopping value is shopping to meet the practical benefits of a purchased product, measured by Likert scale from 1 to 5 .

Hedonic shopping value is shopping to meet the emotional satisfaction (pleasure) of a shopping activity, measured by Likert scale from 1 to 5 .

Shopping behavior is shopping value intended generally to fulfill both the practical benefits and emotional satisfaction of a shopping activity, measured by Likert scale from 1 to 5 .

Gender refers to the gender of the respondents, measured by nominal scale which 1 is for man respondents and 0 for woman respondent.

\subsection{Estimation Models}

The estimation model in this analysis was emphasized on dummy variable model recommended by Gujarati (2004). The estimation model in this analysis was:

$\begin{array}{lll}\text { Shopping Behavior } & =a+b \text { Dummy Gender }+e\end{array}$

\section{Data Analysis and Discussion}

\subsection{Respondents Description}

There were 200 respondents in this study. However, only 101 of questionnaires or approximately $50.5 \%$ responses were processed. The average age of the respondents was 20.6 years old. They consisted of 39 women(39\%) and 62 man respondents (62\%).

\subsection{Data Validity and Reliability}

Data validity was examined by using Explanatory Factor Analysis (EFA) technique with direct oblimin rotation. The results of the factor analysis test were as follows:

Table 1: Validity Result

\begin{tabular}{|c|l|c|c|}
\hline \multirow{2}{*}{ No. } & Statements & \multicolumn{2}{|c|}{ Factor Score } \\
\cline { 3 - 4 } & & 1 & 2 \\
\hline & Hedonic & & \\
\hline 1 & Shopping in the supermarket is enjoyable & 0.769 & \\
\hline 2. & Shopping in the supermarket is the way to reduce my problems. & 0.583 & \\
\hline 3. & Comparing to another activity, shopping in the supermarket is more enjoyable & 0.589 & \\
\hline 4. & I like to be with more new kind of products. & 0.406 & \\
\hline 5. & I love shopping not due to products that I bought, but because I love the shopping activity. & 0.739 & \\
\hline 6. & I enjoy my leisure time by shopping in the supermarket & 0.508 & \\
\hline 7. & When I go for shopping, I love the satisfaction of looking for products that I want. & 0.657 & \\
\hline 8. & Shopping makes me forget my problems. & 0.515 & \\
\hline 9. & I feel shopping is more like an adventure. & 0.721 & \\
\hline & Utilitarian & & \\
\hline 1 & Shopping in the supermarket is not wasting my time & & 0.746 \\
\hline 2. & I disappointed for going to the supermarket to another supermarket to fulfill my shopping activity. & & 0.404 \\
\hline
\end{tabular}

\section{Source: Data Processed}

Based on Nunnally's criteria (1976), the items in the questionnaire had fulfilled the minimum factor loadings of 0.3 . However the validity test on constructed shopping value was not clumped on its suitable dimension.

The reliability test on PSV instrument is shown in table 4.2. 
Table 2: Instruments of Reliability Test Summary

\begin{tabular}{|c|c|c|}
\hline No. & Variables & Cronbach Alpha Scores \\
\hline 1. & Hedonic & 0.7845 \\
2. & Utilitarian & 0.5024 \\
\hline
\end{tabular}

Source: Processed Data

The reliability test showed Cronbach Alpha score of hedonic dimension was 0.7845. Based on Nunnally's Criteria (1976), the dimension was reliable. However, the Cronbach Alpha score for utilitarian dimension was below the Nunnally's standard, which is 0.6. The score for utilitarian dimension was 0.5024 .

The validity and reliability test resulted elimination of 4 (four) items from PSV instruments because the factor score was less than 0.3 and the Cronbach Alpha score was below 0.6. Moreover, the remaining questions could be used as groundwork to arrange constructed hedonic and utilitarian values.

\subsection{Hypothesis Testing}

Table 3: Regression Analysis with Dummy Variables

\begin{tabular}{|c|c|c|c|}
\hline \multirow{2}{*}{ Independent Variables } & \multicolumn{3}{|c|}{ Dependent Variables } \\
\cline { 2 - 4 } & Shopping Behavior & Hedonic Orientation & Utilitarian Orientation \\
\hline Intercept & $38.231^{\star \star}$ & $31.051^{\star *}$ & $7.179^{\star *}$ \\
Gender & $-4.521^{\star *}$ & $-4.035^{\star *}$ & -0.486 \\
$\mathbf{R}^{2}$ & 0.120 & 0.112 & 0.02 \\
\hline
\end{tabular}

Notes: ${ }^{* *}=$ significant on satisfaction level 0.05

The regression test with dummy variables indicated that gender significantly influenced the shopping behavior and hedonic shopping orientation. On the contrary, gender did not significantly influence the utilitarian shopping orientation.

Based on shopping behavior estimation, the average value of shopping behavior was 38.231 . While gender regression coefficient value was -4.521 , which indicated average value on shopping behavior of man respondents was 33.71 (38.231 - 4.521). The average value was meaningless and only confirmed that men had lower shopping behavior orientation than woman respondents.

The estimation model of hedonic orientation showed the average hedonic orientation score of 31.051. Considering gender coefficient score was -4.035 , it means that the average hedonic orientation score of the man respondents was $27.016(31.051-4.035)$. This average score indicated that man respondents had lower hedonic orientation average score than woman respondents.

The average score of Utilitarian Orientation Estimation Model was 7.179. This model could not be addressed further since the gender variable had insignificant effects on utilitarian shopping orientation.

\subsection{Discussion}

The estimation model of this study presented similar result to Seock and Souls' research (1996) which showed that gender had a contribution on shopping behavior. Woman consumers in this study tended to have higher shopping behavior. The respondents were19-22 years-old women who lived in Solo City . Retailers in Solo City developed their marketing strategy to attract consumers in various ways. This research denoted that woman respondents were more exposed by marketing advertisement created by modern retailers rather than the man respondents.

This research confirmed research by Karim et al. (2013) that utilized hedonic and utilitarian orientation measurement to analyze shopping behavior of modern retail consumers in Malaysia. The research found that woman consumers had a propensity to have hedonic shopping orientation. This study showed that urban women in Solo City also had hedonic shopping orientations. Their activities were not solely intended to purchase products, but also due to emotional and psychological aspects, including pleasure, hunting products, and social necessity fulfillment.

The findings in this research indicated that urban women in Solo City were vulnerable as potential marketing target. They might be interested with additional facility of the modern retails. Furthermore, the additional facility was intended to meet psychological and social necessity of woman consumers. The segmentation strategy based on gender was relevant to determine the marketing target of modern retails. 


\section{Conclusions and Implications}

Several conclusions can be formulated from the analysis of this study :

1. This research showed the difference of shopping behavior between men and women as reflected by the respondents of this study. Average scores for woman respondents indicated that women have higher shopping behavior in compared with men.

2. Women have a propensity to have higher hedonic shopping orientation than men.

3. Gender has insignificant effect on utilitarian shopping behavior.

The theoretical implication with hedonic and utilitarian shopping behavior dimensions in this study explained properly the phenomenon of urban women shopping behavior. It means that Personal Shopping Value (PSV) instrument developed by Griffin et al. (2000) was relatively accurate measuring tool to examine shopping behavior.

The practical implication of this study was the relevancy of demographic factors to arrange segmentation analysis for retail companies. Retail companies are supposed to give additional benefits such as facility to fulfill psychological and social necessity of urban women during their shopping activities.

\section{References}

Assael, H (1998).Consumer Behavior and Marketing Action. 6 thEd., New York South Western College Publishing.

Babin, B.J. and Babin, L. (2001), "Seeking Something Different? A Model Of Schema Typicality, Consumer Affect, Purchase Intentions And Perceived Shopping Value", Journal Of Business Research, Vol.54, Pp. 89-96.

Badgaiyan A.J and Verma .A (2015), Does urge to buy impulsively differ from impulsive buying behaviour? Assessing the impact of situational factors, Journal of Retailing and Consumer Services 22, pp 145-157.

Cha, J. (2001), "Planned And Unplanned Apparel Purchase Typology And Related Variables", Unpublished Thesis, Seoul National University, Seoul.

Duarte. P, Raposo .M, and Ferraz .M (2013), Drivers of snack foods impulse buying behaviour among young consumers, British Food Journal, Vol. 115 No. 9, pp. 1233-1254.

Fiore, A.M and J. Kim, (2007), An Integrative Framework Capturing Experiential And Utilitarian Shopping Experience, International Journal Of Retail \& Distribution Management, Vol. 35 No. 6, Pp. 421-442.

Griffin, M, B.J Babin, and D. Modianos (2000), Shopping Values of Russian Consumers: The Impact of Habituation in a Developing Economy, Journal of Retailing, Vol 76, No.1.

Gujarati, Damodar (2004). Basic Econometrics.,Boston. McGraw Hill International.

Hair Joseph F, Rolph E Anderson, Ronald L Tatham, and William C Black (2010), Multivariate Data Analysis Fifth Edition, New Jersey, Prentice Hall.

Hausman, A. (2000), "A Multi-Method Investigation Of Consumer Motivations In Impulse Buying Behavior", Journal Of Consumer Marketing, Vol. 17 No. 15, Pp. 403-19.

Isen, A.M., Niedenthal, P.M.,and Cantor, N. (1992), "An Influence Of Positive Affect On Social Categorization", Motivation And Emotion, Vol. 16, Pp. 65-78.

Jones, M.A., Reynolds, K.E., Weun, S., and Beatty, S.E. (2003), "The-Product-Specific Nature Of Impulse Buying Tendency", Journal Of Business Research, Vol. 56 No. 7, Pp. 505-11.

Karim,J.A, M. Kumar,and S. Abd Rahman, (2013) Measuring Shopping Values Of Malaysian Retail Consumers, Asia Pacific Journal Of Marketing And Logistics Vol. 25 No. 2, Pp. 200-224.

Kelly. M, Seubsman. S, Banwell. C, Dixon .J and Sleigh .A (2015), Traditional, modern or mixed? Perspectives on social, economic, and health impacts of evolving food retail in Thailand, Agriculture And Human Values, 32: pp 445-460.

Lee, A.Y. and Sternthal, B. (1999), "The Effect Of Positive Mood On Memory", Journal Of Consumer Research, Vol.26, Pp. 115-27.

Meloy, M.G. (2000), "Mood-Driven Distortion Of Product Information", Journal Of Consumer Research, Vol. 27, Pp. 345-59.

Millan E.S and E. Howard, (2007), Shopping For Pleasure? Shopping Experiences Of Hungarian Consumers, International Journal Of Retail \& Distribution Management Vol. 35 No. 6, Pp. 474-487.

Park E.J, E.Y Kim,and J. C.Forney (2006), A Structural Model Of Fashion-Oriented Impulse Buying Behavior, Journal Of Fashion Marketing And Management, Vol. 10 No. 4, pp. 433-446.

Piron, F. (1991), "Defining Impulse Purchasing", Advances In Consumer Research, Vol. 18, Pp. 509-13.

Samuel, S.N, E. Li,and H. McDonald, (1996), The purchasing behaviour of Shanghai buyers of processed food and beverage products: implications for research on retail management, International Journal of Retail \& Distribution Management Volume $24 \cdot$ Number 4, pp. 20-28.

Seo, J., Hathcote, J.M., and Sweaney, A.L. (2001), "Casual Wear Shopping Behavior Of College Men In Georgia,USA", Journal Of Fashion Marketing And Management, Vol.5No.3, Pp. 208-22.

Seock, Y.K and N. Sauls, (2008), Hispanic Consumers' Shopping Orientation And Apparel Retail Store Evaluation Criteria, An Analysis Of Age And Gender Differences, Journal Of Fashion Marketing And Management, Vol. 12 No. 4, pp. 469-486.

Shandilya, A.K (2014), Urban Consumers' Preference for Organised and Unorganised food retailing in the state of Jharkhand, India, International Journal of Hospitality \& Tourism Systems, Volume 7 Issue 2 December, pp 9-18. 